\title{
INTELlectual PROPERTY, Business AND ChINA: TAKING A STAND
}

\author{
JANE L MenZIES*
}

\section{LIDIA XYNAS ${ }^{* *}$}

\section{STUART ORR ${ }^{* * *}$}

\section{MONA CHUNG ${ }^{* * * *}$}

Over the last 40 years, China has developed laws for the protection of intellectual property rights. Unfortunately, these laws have not been uniformly enforced, making such protection problematic for Australian and other foreign organisations wishing to do business in China. This article first scrutinises the current Chinese laws covering intellectual property protection. It then examines the outcomes of a qualitative study that addressed intellectual property protection issues faced by selected Australian organisations conducting business with Chinese counterparts located in China. Forty Australian business managers/owners from Australian companies having business relationships with Chinese firms were interviewed for this study. The findings show that protection issues are only relevant to certain types of businesses that have intellectual property to protect. Nevertheless, a number of the managers/owners interviewed believed that infringement threats were real and inevitable in China, and some had even experienced cases of copying. The study found that, despite such concerns, there was little evidence of organisations taking proactive and positive steps to adequately protect their intellectual property. In order to address this, the authors of this article have developed a protection strategy that incorporates the use of the law, together with firms' organisational designs, so that foreign firms can protect their rights when interacting with the Chinese market.

\footnotetext{
${ }^{*}$ Lecturer, Graduate School of Business, Deakin University. Some parts of this article are based on 'Intellectual Property in China: Are the Issues All They Are Cracked Up to Be?' in Jane L Menzies, Mona Chung and Stuart Orr, Doing Business in China: Getting Ready for the Asian Century (Business Experts Press, 2012) 97-114.

${ }^{* *}$ Lecturer, School of Law, Deakin University.

*** Professor, Graduate School of Business, Deakin University.

**** Lecturer, School of Management and Marketing, Deakin University.
} 


\section{INTRODUCTION}

China has come a long way since the late 1970s when its government initiated an 'open-door' policy, seeking to bring to an end the economic isolation that had existed since the birth of the People's Republic of China ('PRC') in 1949. Foreign trade and investment are now strongly encouraged and foreign investors have swarmed in to 'chase the dragon'. ${ }^{1}$ The government has devised both economic and legal incentives to attract overseas investment. ${ }^{2}$

In 1979, China began active participation in the international economy. In the two decades that followed, the country's top-level legislature, the National People's Congress ('NPC') and its Standing Committee, passed or amended over 300 laws in an effort to change the stagnant state of economic law and bring China's economic development into line with the international rule of law. $^{3}$

As China accelerated its industrialisation and hosted more foreign investment, intellectual property issues began to emerge, creating the need to implement a complete legal regime for the protection of intellectual property rights. ${ }^{4}$ In addition, Western countries also began to lobby for more effective intellectual property protection in China. Chinese leaders recognised that intellectual property protection was one of the legal cornerstones ${ }^{5}$ required for its economic reform and integration into the global market. It therefore moved to strengthen the law in that area by instituting domestic legislation, and by becoming party to relevant international agreements. In 2001, China became a member of the World Trade Organization ('WTO'), signifying its commitment to being a major world trade player. Intellectual property was

\footnotetext{
1 The dragon is a traditional symbol of China. See Jim Rohwer, 'The Titan Stirs', The Economist, 28 November 1992 <http://www.tibet.ca/en/newsroom/wtn/archive/old?y=1992 \&m=12\&p=15_1>.

${ }^{2}$ Economic incentives include: tax breaks, operational autonomy, liberalisation of the domestic market, and the opening-up of domestic industries, such as transportation, retail and banking.

${ }^{3}$ Yan Wang, Chinese Legal Reform: The Case of Foreign Investment Law (Routledge, 2002) 1.

${ }^{4}$ See Peter Butt (ed), Butterworths Concise Australian Legal Dictionary (Butterworths, $3{ }^{\text {rd }}$ ed, 2004) 227 where 'intellectual property rights' are defined as: 'A group of legislative and common law rights affording protection to creative and intellectual effort and includes laws on copyright, design, patent, circuit layouts, plant varieties, confidential information, trade mark and business reputation (passing off and trade practices). Intellectual property encompasses both industrial property (patent, design and trade mark) as well as intellectual property.'

${ }^{5}$ In 1986, the General Principles of the Civil Law (PRC) 1986 recognised the intellectual property rights of citizens and legal persons. See ch V, s 3, arts 94-7 <http://www. npc.gov.cn/englishnpc/Law/2007-12/12/content_1383941.htm>.
} 
soon politically recognised as the engine for China's modernisation. ${ }^{6}$ The intellectual property protection system in China today is heavily legislated, offering (on paper at least) significant protections to local and foreign intellectual property owners. In fact, China's intellectual property laws are on a par with those in countries such as Australia.

This article will examine the current protections of intellectual property available in China, in particular, the laws protecting patents, copyrights and trade marks. The advantages of such legislation are noted, as are the limitations of these laws as they apply to Australian and other foreign organisations doing business in China.

Next, the article will examine some of the underlying reasons for intellectual property infringement in China, which continues despite China's WTO accession and the introduction of detailed domestic intellectual property laws.

Against this background of endemic infringement, the authors undertook a qualitative study of 40 Australian organisations. The major hypothesis tested by the study was that Australian organisations would be concerned about their intellectual property protections when operating in China. In addition, the researchers hypothesised that these organisations would pursue legal action in order to address infringements of their intellectual property in China. The findings of the study, however, were not conclusive regarding either hypothesis. It was found that only some organisations were proactively implementing strategies to protect their intellectual property. In addition, it was found that, given the perceived problematic enforcement regime in China with regard to intellectual property protection, many organisations took alternative steps (rather than turning to the law) to protect their intellectual assets. For example, some organisations incorporated infringement costs into the cost base of their goods, whilst others simply accepted infringement as a problem to be tolerated.

Based on the varied findings, and the demonstrated lack of intellectual property protection strategies used by many of these organisations, the authors of this article have developed a framework that organisations can use to conceptualise the protection of their intellectual assets when operating and doing business in China.

\footnotetext{
${ }^{6}$ People's Republic of China State Council, Intellectual Property Protection in China (June 1994) China.org.cn <http://www.china.org.cn/e-white/intellectual/index.html>. The Foreword to the White Paper notes that the objectives underlying the development of China's intellectual property system are 'to rapidly develop social productive forces, promote overall social progress, meet the needs of developing a socialist market economy and expedite China's entry into the world economy'.
} 
In addition to the strategies recommended, the authors conclude that, despite the various problems encountered with intellectual property protection by many organisations doing business in China, the rise of innovative China ${ }^{7}$ foreshadows a positive future for intellectual property protection in that country. The Economist reported that, as China becomes more innovative, it will take intellectual property more seriously; if it is protected, then the Chinese will produce more intellectual property-related products. If inventions are protected, the Chinese people will generate more of them. ${ }^{8}$ Indeed, the current Australian Prime Minister, Kevin Rudd commented in 2011 that 'with [the Chinese people] starting to develop their own products and intellectual property, the importance they place on intellectual property will increase as a result of their need to protect their own intellectual property'. ${ }^{9}$ Arguably, this should create the impetus for China to protect the intellectual property of international businesses in China. In this way, the economic and business market in China can benefit all players, both foreign and local.

\section{Current Intellectual Property Laws in China}

In order to welcome foreign investment after having adopted an economic reform policy, China passed several pieces of intellectual property legislation starting in 1982 with the Trademark Law of the People's Republic of China (PRC) 2001 and its implementation laws as revised in 1988. ${ }^{10}$ In 1985, the Patent Law of the People's Republic of China (PRC) 1994 and its implementation rules were made effective, and, in 1990, the Copyright Law of the People's Republic of China (PRC) 2001 was adopted, and its implementation rules came into effect in $1991 .^{11}$ In addition, the Foreign Trade Law of the People's Republic of China (PRC) 2004 was adopted in 1994, which specifies that the infringement of protected intellectual property under Chinese law constitutes an unfair and illegal act. ${ }^{12}$

\footnotetext{
${ }^{7}$ Comment, 'Innovation in China: From Brawn to Brain', The Economist, 10 March 2012 $<$ http://www.economist.com/node/21549938>.

${ }^{8}$ Ibid.

${ }^{9}$ Kevin Rudd, ‘Australia China 2.0 Trade Mission' (Speech delivered at the Australia China Business Council briefing, The Grand Hyatt, Melbourne, 14 July 2011).

10 Jianfu Chen, Chinese Law: Towards an Understanding of Chinese Law, Its Nature and Development (Kluwer Law International, 1999) 347.

${ }^{11}$ Ibid 348.

${ }^{12}$ Article 2 of the Foreign Trade Law of the People's Republic of China (PRC) 2004 states: 'This Law shall apply to foreign trade and intellectual property protection relevant to foreign trade.' Article 29 states: 'The State shall, in accordance with the laws and administrative rules and regulations concerning intellectual property rights, protect intellectual property rights
} 
China also became a member of the World Intellectual Property Organization (WIPO) in 1980, and ratified the Paris Convention for the Protection of Industrial Property ${ }^{13}$ in 1985, and the Berne Convention for the Protection of Literary and Artistic Works in 1992. ${ }^{14}$ It also signed and ratified the Madrid Agreement Concerning the International Registration of Trademarks ${ }^{15}$ in 1989, and the Patent Cooperation Treaty (PCT) in 1992. ${ }^{16}$

Much of the evolution and implementation of China's intellectual property laws was the result of various types of pressure, and China's need for foreign investment. United States pressure forced China to expand its intellectual property protection capacity. China was also required, as part of its WTO membership agreement, to implement legal protections of an internationally accepted standard, which could be relied upon by foreign parties. The undertaking to protect foreign interests was further secured by the SinoUnited States agreement on China's accession to the WTO, whereby China agreed to bring its intellectual property rights laws fully into compliance with the Trade-Related Aspects of Intellectual Property Rights (TRIPS) agreement. $^{17}$

Within the framework established, China has been able to pursue a gradual process of implementing its intellectual property regime in such a way that 'the scope of protection of IPR and the standard for such protection are made to correspond to the level of economic development'. ${ }^{18}$ Since its accession to the WTO, China's intellectual property laws have been further developed and adapted to ensure that they are acceptable at an international level. Indeed, the WIPO has stated that China now has one of the top patent offices in the world, and has the world's largest trade mark office. ${ }^{19}$ In 2008, China released its

relevant to foreign trade. Upon those imports violating intellectual property rights and endangering the order of foreign trade, the competent department in charge of foreign trade under the State Council may adopt measures to prohibit the export of relevant goods produced or sold by the pirates for a certain period.'

${ }^{13}$ Paris Convention for the Protection of Industrial Property, opened for signature 20 March 1883 (entered into force 19 May 1970).

${ }^{14}$ Berne Convention for the Protection of Literary and Artistic Works, opened for signature 9 September 1886 (entered into force 5 December 1887).

${ }^{15}$ Madrid Agreement Concerning the International Registration of Marks, opened for signature 14 April 1891.

${ }^{16}$ Chen, above n 10, 348.

${ }^{17}$ Qingjiang Kong, WTO, Internationalization and the Intellectual Property Rights Regime in China (Times Academic Press, 2005) 4.

${ }^{18}$ Ibid 1.

19 WIPO, Summary of the Patent Cooperation Treaty (PCT) (1970) (2011) <http://www.wipo.int/treaties/en/registration/pct/summary_pct.html>. 
national intellectual property strategy. ${ }^{20}$ On 14 March 2011 the National People's Congress approved China's $12^{\text {th }}$ Five-Year Plan (2011-15) which focuses, inter alia, on furthering efforts to create an innovative and knowledge-based economy. ${ }^{21}$ As a result of its legislative initiatives, China's intellectual property laws are now very similar to those in developed countries such as Australia, and should today provide domestic and foreign owners of intellectual property with effective protection.

The article will next examine the intellectual property laws of China more closely, with a view to determining how harmonious they are with the intellectual property laws of other states, and whether they afford practical protection of intellectual assets.

\section{A Patent Law and Process}

Economic growth theory suggests that investment in education, research and development are factors that influence economic development. ${ }^{22}$ Therefore, to promote economic development, the Patent Law of the People's Republic of China was promulgated to encourage science and technology, and also to stimulate new inventions. This legislation is quite well developed, having been amended three times (in 1992, 2000 and 2009) since it was first promulgated in 1984 in order to extend its scope. The amendments made in 1992 extended the list of patentable subject matter by the inclusion of pharmaceutical compositions, as well as recognising China's membership of the PCT. The 2000 amendments took into account China's obligations under the TRIPS Agreement, of which it had become a member. The third set of amendments, adopted as law on 1 October 2009, further strengthened patent protection in China by, inter alia, adopting a new novelty standard under article 22.2, which now gives recognition to public use outside of China. This will be especially important for those challenging patent validity in China.

Membership of the PCT means that any organisation that makes a single patent application in one member country can have that patent apply in other member countries. ${ }^{23}$ Articles 18 and 19 of the Chinese Patent Law provide for foreign patent registrations in China. Article 18 provides that, where a

\footnotetext{
${ }^{20}$ Ibid.

21 KPMG, China's 12 ${ }^{\text {th }}$ Five-Year Plan: Overview (2011) <http://www.kpmg.com/cn/en/ IssuesAndInsights/ArticlesPublications/Documents/China-12th-Five-Year-Plan-Overview201104.pdf $>$.

22 See Wei-Bin Zhang, Economic Growth Theory, Capital, Knowledge and Economic Structures (Ashgate Publishing, 2005) 4-10 [1.2] for an overview of differing economic growth theories espoused by a number of writers.

${ }^{23}$ WIPO, above n 19.
} 
foreigner or foreign entity does not have residence or a business office in China, it can still receive patent protection, as a domestic entity would, so long as the patent is registered in China in accordance with Chinese law and the Paris Convention. However, an application must be lodged with the PCT for this to apply. This avenue is available to Australian organisations wanting to register a patent in China because both Australia and China are members of the PCT. However, article 19 of the Chinese Patent Law notes that, in order for foreign-owned patents to receive such protections under Chinese law, it is essential that foreign organisations 'entrust lawfully established patent agencies' to act as their agents. These patent agencies, approved by the State Intellectual Property Office (SIPO) ${ }^{24}$ register the patents, which have been previously translated into Chinese. SIPO is the 'coordinating agency when foreign-related intellectual property issues are involved'. ${ }^{25}$ SIPO has the responsibility for administering patents, which are registered through the Chinese Patent Office.

Under Chinese Patent Law, China has two forms of patents: invention patents and utility patents. Under article 42, invention patents (similar to Australia's standard patents) are valid for 20 years. Utility patents, available for lower level inventions, are valid for 10 years under article 19. Under article 9, an inventor can apply for both an invention and a utility patent for the same invention. Under articles 2 and 19, designs (for example those relating to fashion, interior design, building, architecture, and engineering) can also be patented, and these are valid for 10 years. Importantly, China follows a 'firstto-file' policy, detailed in articles 28, 29 and 30 of the Patent Law. This aspect of the law can be problematic for foreign firms in some circumstances. In effect, it means that if an organisation in a foreign country has developed a technology, a Chinese organisation can 'pilfer' and patent that same technology in China, and there is no requirement for the Chinese organisation to prove that it developed the technology. ${ }^{26}$ Simply being the first to patent the technology first guarantees enjoyment of its patent rights in the Chinese

24 IP Australia, IP Passport: China (Fact Sheet) (2009) <http://www.ipaustralia.gov.au/ pdfs/factsheets/ippassport_china.pdf $>$.

${ }^{25}$ SIPO, Overview (2008) <http://www.sipo.gov.cn/sipo_English2008/about/basicfacts/200904/ t20090415_451001.html>.

26 See Canadian Commissioner Trade Service, Patent Options in China (2010) $<$ http://www.tradecommissioner.gc.ca/eng/document.jsp?did=118690 $>$, where it is noted that 'China's pace of patent filings is increasing dramatically, especially in terms utility model patents. Since utility model patents do not require any substantive examination, and are cheaper and quicker to file, there are a significant number of utility model patents out there and you will want to take precautions to make sure that you are not infringing another party's rights'. 
market. ${ }^{27}$ Therefore, when the foreign firm enters the Chinese market with that same technology, and employs it in China, there is the danger that legal action may be taken against the foreign organisation by the Chinese organisation that had previously patented the (derivative) technology.

\section{B Copyright Law and Process}

Copyright is primarily governed by the Copyright Law of the People's Republic of China, which was promulgated in 1990. The Implementing Rules for the Copyright Law were made in 1991, amended in October 2001 and again in January 2010. Copyright under article 3 covers works including:

work(s) of literature, art, natural science, social science, engineering technology, etc., existing in any of the following forms:

(1) Written works;

(2) Oral works;

(3) Musical, dramatic, quyi, choreographic, and acrobatic works;

(4) Fine art and architectural works;

(5) Photographic works;

(6) Cinematographic works and works created by means similar to cinematography;

(7) Graphic works including engineering design drawings, product design drawings, maps, schematic drawings, etc., as well as model works;

(8) Computer software; and

(9) Other works specified in laws and administrative regulations.

In 1991, the State Council in China passed the Computer Software Protection Rules. ${ }^{28}$ As a result, software is now treated as a form of literary work, and the rules on the registration, examination and approval of computer software programs in China are now specified in article 3 of the Copyright Law.

Under the Copyright Law, article 11, the author is the lawful owner of the work by virtue of having intellectually created it. Under article 10, owners of copyright have a number of personal and property rights in their works. For example, an individual who holds the copyright has the sole right to prevent others from copying, reproducing, publishing or broadcasting the work

\footnotetext{
${ }^{27}$ A K Gupta and H Wang, 'Safeguarding Your Intellectual Property in China', Business Week, 20 May $2011<$ http://www.businessweek.com/globalbiz/content/may2011/gb20110520_ 313022.htm>.

${ }^{28}$ Regulations on Computers Software Protection (PRC) State Council of the People's Republic of China, Decree No 339, 20 December 2001.
} 
without authorisation. Article 21 notes that copyright protection lasts for the life of the author plus 50 years. Article 21 stipulates that, for movies and photographic materials created by organisations, the copyright lasts for 50 years after the material was first created or published. ${ }^{29}$ Under article 20, however, the protection of an author's rights of authorship, alteration, and integrity are not subject to a time limit.

Article 2 of the Copyright Law clearly states that foreign authors can obtain copyright protection for their works that have been first produced or published within China. Article 2 also covers the protection of foreign works that are produced or published outside China. ${ }^{30}$ Since Australia and China are both members of the Berne Convention, any copyright attached to one jurisdiction can enjoy protection in both jurisdictions; it does not matter whether the works were first published or made in Australia or China, or any other member country. In addition, article 16 of the Chinese Copyright Law states that, where the work was created in fulfilment of a task assigned to the author by an organisation or other legal person (this may include employers), it will be deemed as a 'work for hire'. In this case the copyright in the work remains the creator's; however, the employer has priority in the use of that work within the scope of its business activities. Therefore, if the work was brought into existence in an Australian-owned company, copyright is owned by its creator but the company has priority to use the work within its business activities. Only after two years from the creation of the work can the creator of the work allow a third party to use the work in the same way in which his or her employer is using it, unless the employer grants permission for such use prior to this period ending. The creator of the work will enjoy full rights of authorship (moral rights) under the law; however, his or her employer can exercise the other copyright rights, for which the creator may be remunerated or rewarded.

Contrast this with article 11, which states that:

With respect to a work created under the sponsorship of, and according to the intention of, any legal person or any other organisation that bears the responsibility for the work, such legal person or other organisation shall be deemed the author of the work.

\footnotetext{
29 See also IPR in China, Copyright Law to Be Revised (2011) <http://www.chinaipr. gov.cn/lawsArticle/laws/lawsar/copyright/201107/1239509_1.html>.

${ }^{30}$ Copyright Law of the People's Republic of China (PRC) 1990, art 2: 'Where a foreigner or stateless person enjoys copyright in his or her work under an agreement concluded between China and the author's country or origin or country of habitual residence, or an international treaty to which both that country and China have acceded, such copyright shall be protected under this Law.'
} 
This indicates different treatment of copyright ownership in the case where a work is not classed as a 'work for hire'. In such a situation, if the work is created under 'sponsorship' - that is, where the company actually bears all the responsibility (and most likely the cost) of the work - then it is the company or the employer who owns the copyright and can enjoy all rights under the Copyright Law, without the need to consider remunerating or rewarding the actual creator of the work.

In addition, it is important to note that whilst registration of copyright is not compulsory in China, it is available and recommended because a certificate of registration is prima facie evidence of ownership. This is in contrast to the recognition of copyright under the Australian Copyright Act 1968 (Cth). In Australia, works do not require registration and copyright subsists automatically. ${ }^{31}$ Registering copyright in China allows a copyright holder to lodge an infringement complaint with the Copyright Bureau, and request that the Copyright Bureau take action. $^{32}$ Registration, under new draft amendments of the Chinese Copyright Law, is being strongly encouraged. ${ }^{33}$

\section{Trade Mark Law and Process}

In China, it is the Trade Mark Office that oversees the registration and administration of trade marks. This central government department reports directly to the State Administration for Industry and Commerce ('SAIC'). The law for trade mark protection in China is contained in the Trademark Law of the People's Republic of China (PRC) 2001. It was first enacted in 1982, and subsequently amended in 1993 and 2001. The law was created to improve the administration of trade marks, to specify the protection of trade mark owners' exclusive rights, to encourage producers to ensure and maintain the quality of their products or services in order to preserve the value of the trade mark, and also to assist with protecting consumer interests. Article 17 of the Trademark

\footnotetext{
${ }^{31}$ LexisNexis Australia, Kevin Lindgren, James Lahore and Warwick A Rothnie, Copyright and Designs (2013) [12,000]: 'No formalities are required for the subsistence of copyright in Australia under the Copyright Act 1968 (Cth). Copyright subsists by virtue of the operation of the Act in certain subject matter where there exists the appropriate connecting factor. There is no system of registration of copyright, voluntary or compulsory.'

${ }^{32}$ Hong Kong Trade Development Council, Practical Guide to IPR Protection in China How to Protect Your Brand? (2005) <http://info.hktdc.com/chinaipr/ipr.htm>.

33 On 31 March 2012, the National Copyright Administration of PRC ('NCAC') proposed further changes to the Chinese Copyright Law. The changes include: expanding the scope of copyright works, encouraging copyright registration, expanding copyright protections to encompass resale royalty rights, providing for clearer rules which govern copyright ownership, making copyright protection available to those dealing on the internet, increasing damages available under statute, and giving copyright enforcement agencies more administrative powers <http://www.ncac.gov.cn/cms/html/309/3502/201203/740608.html>.
} 
Law provides for the protection of foreign-owned trade marks. Since Australia and China are both members of several international agreements, including the Madrid Agreement and the Paris Convention, trade marks attached to either jurisdiction can enjoy protection in both jurisdictions. Nevertheless, a foreign applicant whose country of residence is not a member of the international agreements may still be able to apply for trade mark recognition in China on the basis of 'the principle of reciprocity' (found in article 17 and discussed in more detail below). Under this principle, if some special requirements are imposed on Chinese applications for trade mark registration in a foreign country, China will impose equivalent conditions or requirements on applicants or applications from that country.

It should also be noted that in China exclusive rights can generally be relied on only after registration of the trade mark. ${ }^{34}$ Unlike Australian law, Chinese law provides no common law protection for unregistered trade marks; it contains no common law actions such as 'passing off' ${ }^{35}$ Importantly, under articles 24-5, 29 of the Trademark Law, China follows a 'first-to-file' rule for obtaining trade mark rights, which means that the first person to file a trade mark registration application will generally have priority over a prior user of the same trade mark in China. In effect, foreign firms which deal in trade marked goods in the Chinese market must ensure that their trade marks are registered with the relevant Chinese authorities.

\section{Other Protections Offered for Intellectual Property Rights in China}

As both China and Australia are WTO members, both countries must ensure that their intellectual property laws are consistent with the TRIPS Agreement.

\footnotetext{
${ }^{34}$ Trademark Law, arts 37, 51. The exception is for 'well-known trademarks' (see arts 13-4). These trade marks are now also recognised under Chinese law. The courts and administrative bodies will take into account 'the cognition of the mark among the relevant public, length and continuous use of the mark, continuous length of time, degree and geographical scope for promoting the mark, record of protection of the mark as a well-known mark and any other factors related to the mark's well-known status'.

${ }^{35}$ Passing off is a common law tort, which can be used to enforce unregistered trade mark rights. Passing off essentially occurs where the reputation of party $\mathrm{A}$ is misappropriated by party B, such that party B misrepresents this reputation and damages the goodwill of party A. The law prevents one person from misrepresenting his or her goods or services as being the goods and services of the plaintiff, and also prevents one person from holding out his or her goods or services as having some association or connection with the plaintiff when it is not true.
} 
This agreement helps to ensure that the obligations of other intellectual property protection agreements are adhered to by its members. ${ }^{36}$

The Chinese government has also negotiated/is negotiating some important bilateral agreements, including the 1979 bilateral trade agreement with the United States under which each country has agreed, on the basis of nondiscrimination, that they should:

grant each other most-favored-nation treatment, establish commercial and trade institutions, protect each other's patterns of trade, copy rights and trade marks and resolve bilateral trade issues through negotiations. This trade agreement came into effect on February 1, 1980. ${ }^{37}$

In 2005 China also entered into negotiations with Australia with a view to adopting a free trade agreement ('FTA') between both countries. During these negotiations, intellectual property protections were addressed, amongst other issues. ${ }^{38}$ To date, there have been 19 rounds of negotiations, the latest one held on 4-6 June 2013. Because of the complexity of the trade-related issues to be covered, the China-Australia FTA is yet to be finalised, although it was noted by the Australian Department of Foreign Affairs and Trade that good progress was being made. ${ }^{39}$

\footnotetext{
${ }^{36}$ WTO, Understanding the WTO - Intellectual Property: Protection and Enforcement (2007): 'The TRIPS agreement covers five issues: 1 . How basic principles of the trading system and other international intellectual property agreements should be applied. 2. How to give adequate protection to intellectual property rights. 3. How countries should enforce those rights adequately in their own territories. 4. How to settle disputes on intellectual property between members of the WTO, and 5. Special transitional arrangements during the period when the new system is being introduced' <http://www.wto.org/english/thewto_e/whatis_ e/tif_e/agrm7_e.htm>.

${ }^{37}$ Zhou Shijian, China-US Economic Relations: Accords and Discords (27 February 2012) China Today <http://www.china.org.cn/opinion/2012-02/27/content_24744473.htm>. See also article II-1, of the People's Republic of China Trade Relations Agreement, Agreement on Trade Relations between the United States of America and the People's Republic of China, 1979 which outlines the 'most favoured nation' treatment <http://tcc.export.gov/Trade_ Agreements/All_Trade_Agreements/People_China.asp>.

${ }^{38}$ Australian Government, Australia, China FTA Negotiations, First Round of Negotiations (25 May 2005) Department of Foreign Affairs and Trade <https://www.dfat.gov.au /fta/acfta/050526_subscriber_update.html>.

${ }^{39}$ Australian Government, The $19^{\text {th }}$ round of negotiations on the Australia-China Free Trade Agreement (FTA) negotiations, (6 June 2013) Department of Foreign Trade and Affairs $<$ https://www.dfat.gov.au/fta/acfta/130606_subscriber_update.html>.
} 
China's membership of the Paris Convention, ${ }^{40}$ the Berne Convention ${ }^{41}$ and the Universal Copyright Convention ${ }^{42}$ also indicates China's commitment to the international community to protect intellectual property rights.

China has also adopted the WTO's concepts of 'national treatment' and 'most-favoured nation'. The concept of 'national treatment' means that the nationals of foreign states must be given 'the same treatment as one's own nationals'. ${ }^{43}$ Under the current Chinese intellectual property Laws, China practises the concept of reciprocity, treating foreign-owned intellectual property as the foreign country would treat the Chinese-owned intellectual property. $^{44}$

Under 'most-favoured nation' treatment, countries cannot discriminate against other WTO members. ${ }^{45}$ Therefore, since China is a member of the WTO, its intellectual property rights laws for the protection of foreign-owned intellectual property are automatically extended to other WTO member states such as Australia when their intellectual property is used within China.

The Chinese intellectual property legislation has been developed based on international standards, and Chinese domestic intellectual property laws, as described above, are extremely detailed, covering all major areas of concern. Nevertheless, the intellectual property protection system in China, especially for the foreign owner, is far from satisfactory for various reasons, several of which are now examined.

${ }^{40}$ China became a member state of the Paris Convention for the Protection of Industrial Property effective on 19 March 1985.

${ }^{41}$ China became a member state of the Berne Convention for the Protection of Literary and Artistic Works effective on 15 October 1992.

${ }^{42}$ China became a member state of the Universal Copyright Convention on 30 October 1992.

${ }^{43}$ WTO, Understanding the WTO - Principles of the Trading System (2007) <http://www.wto. org/english/thewto_e/whatis_e/tif_e/fact2_e.htm\#national>.

${ }^{44}$ For example, under art 2, of the Chinese Copyright Law, it is noted that Chinese citizens and foreigners alike (whether the foreign person enjoys copyright in their work under an agreement between China and the foreigner's own country or under an international treaty to which both China and the other country have acceded) 'shall enjoy copyright in his or her work first published in China in accordance with this Law'.

${ }^{45}$ WTO, above n 43. 


\section{Why Intellectual Property Protection in China IS FAR FROM SATISFACTORY}

\section{A Piracy and Enforcement}

There is a worldwide market for pirated goods. ${ }^{46}$ Growing consumerism has increased the counterfeiting of luxury goods to make them available to those who simply could not otherwise afford these high-end products. China is well known as the country of the fake Gucci'TM handbag and the pirated DVD, and as a supplier of fake pharmaceuticals. ${ }^{47}$ Statistics reveal that more than half of the pharmaceuticals sold in China are counterfeit, with many such pharmaceuticals available online. This has meant that these counterfeit drugs are also ending up in western countries. ${ }^{48}$ Recently, there have also been reports of counterfeit Starbucks outlets, HMV stores and even counterfeit business schools operating in China. ${ }^{49}$

It is postulated that China in the last 25 years has become the main source of global piracy and counterfeiting (see Figure 1 below). Approximately 75 per cent of counterfeit goods seized at United States borders originate from China. ${ }^{50}$ One commentator has evaluated the extent of the problem in the following terms:

The counterfeiting of trademarks, brands, and other forms of intellectual property in the People's Republic of China ('PRC') is now the most serious counterfeiting problem in the history of the world and appears to still be on the rise. ${ }^{51}$

China's centrality to the problem of, and attempt to address, intellectual property infringement is widely recognised: ' $[\mathrm{N}]$ o country contributes more to the piracy problem, or will play a more critical role in shaping the future of

\footnotetext{
${ }^{46}$ Commentary, 'Brand Protection by Foreign Trademark Owners in China' in M A Cohen, A E Bang and S J Mitchell (eds), Chinese Intellectual Property Law and Practice (Kluwer Law International, 1999) 404.

${ }^{47}$ M Backman, 'China's Counterfeit Culture is Becoming Quite an Education', The Age (Melbourne) 27 March $2007<$ http://www.theage.com.au/news/business/chinas-counterfeitculture-is-quite-an-education/2007/03/27/1174761469475.html>.

${ }^{48}$ Ibid.

${ }^{49}$ Ibid.

${ }^{50} \mathrm{~J}$ Ansfield, 'Lessons of Pirate Row; Beijing's Aggressive Defense of Its Cherished Olympic Logo Shows It Can Stop Counterfeiters, If It Wants To', Newsweek International, 10 January 2005, 45.

${ }^{51}$ Daniel C K Chow, 'Counterfeiting in the People's Republic of China' (2000) 78(1) Washington University Law Quarterly 1, 3.
} 
international piracy ... than China' ${ }^{52}$ The Organisation for Economic Cooperation and Development ('OECD') estimates that international trade in counterfeit and pirated goods was worth around $\$ 250$ billion in 2007. ${ }^{53}$

Nevertheless, a study by Business Software Alliance ('BSA'), which asked consumers whether they had pirated software, revealed that Chinese piracy rates did decline from 86 per cent in 2005 to 78 per cent in 2010 (see Figure 1). ${ }^{54}$ This may suggest that some improvement had been made in intellectual property protection in China. However, when these figures are compared with the world piracy rate - in 2010, 42 per cent of consumers admitted to pirating software - China's piracy rates remain extremely high. The figures therefore suggest that intellectual property infringement is still highly problematic in China.

Figure 1: Software Piracy Rates in China and the World ${ }^{55}$

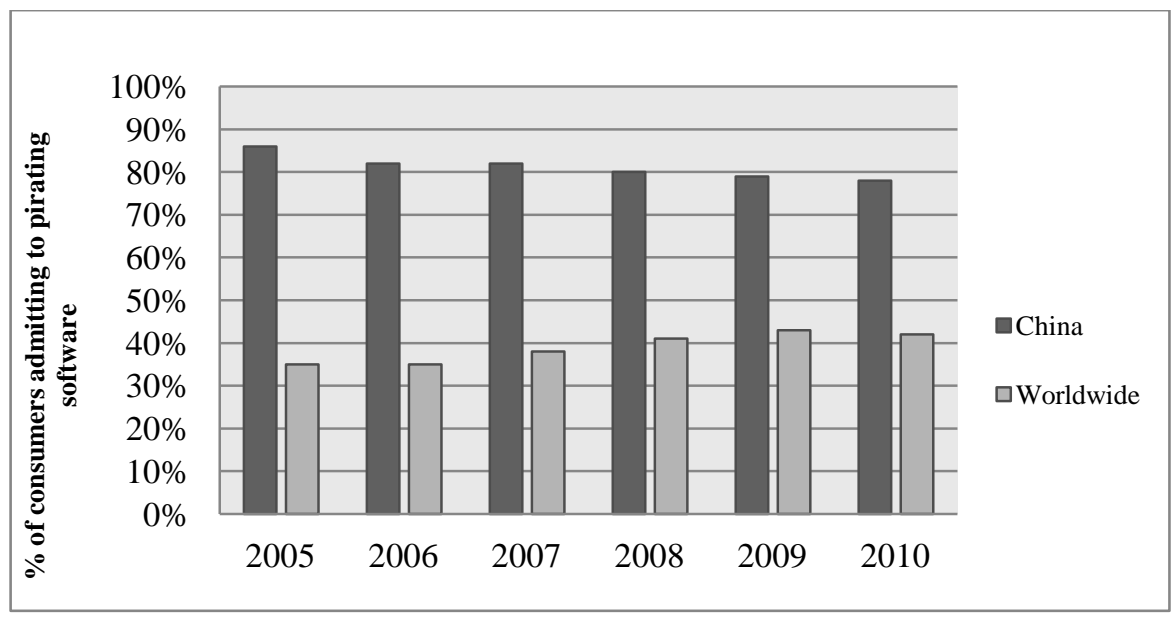

As Figure 1 indicates, software piracy rates in China are declining slightly, whereas worldwide figures show a slight increase. Despite the decreases in piracy rates experienced in China, financial losses from piracy activities in China and the world have been increasing (Figure 2).

${ }^{52}$ Eric Priest, 'The Future of Music and Film Piracy in China' (2006) 21 Berkeley Technology Journal 796, 796.

53 OECD, Magnitude of Counterfeiting and Piracy of Tangible Products: An Update (November 2009) <http://www.oecd.org/industry/industryandglobalisation/44088872.pdf> .

${ }^{54}$ BSA, Global Piracy Study (2010) <http://www.bsa.org/globalstudy>. The Global Piracy Study surveys over 15000 software consumers and users in nearly 100 countries and asks respondents whether they pirate software.

${ }^{55}$ Created by the authors from BSA data over the years. 
Figure 2: Software Piracy Losses in China and the World ${ }^{56}$

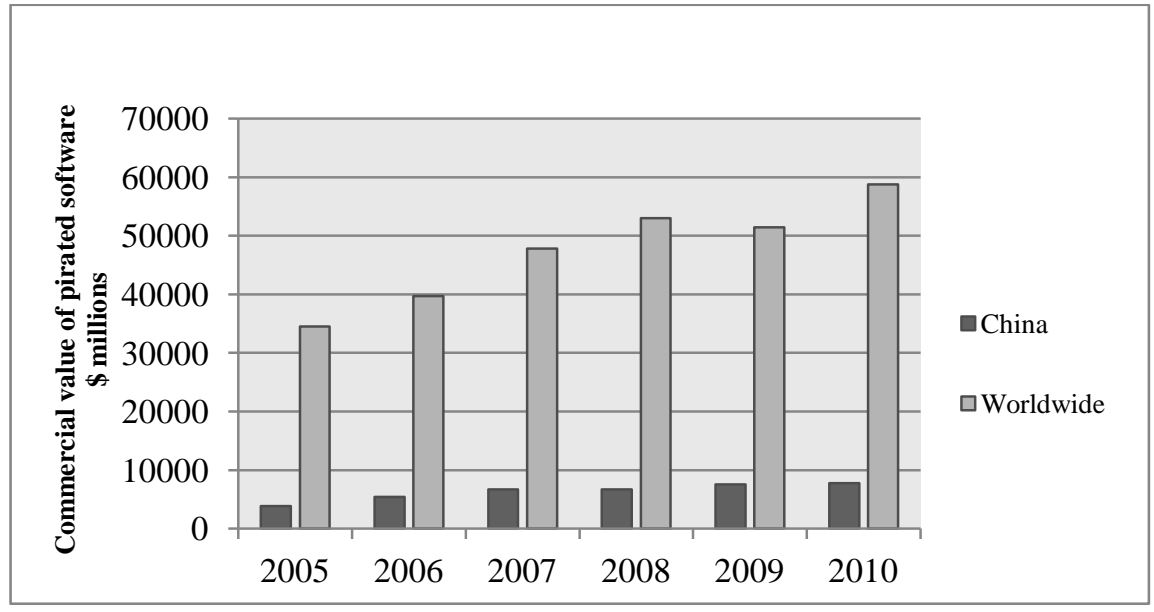

Today, counterfeiters have become experts. They not only make counterfeit products but they also illegally appropriate intellectual capital by making use of the internet which has greatly facilitated the flow of information. ${ }^{57} \mathrm{~A}$ decade ago, almost all counterfeit products used only well-known brands and were based on outsourcing; that is, physical access to 'real' products was required. Today, however, the internet provides anyone with the facilities to download company information such as trade marks and brand designs. ${ }^{58}$ Indeed, some companies that have no business in China and have no plans to enter the Chinese market can suddenly find pirated versions of their own products being sold in China and exported to other countries. ${ }^{59}$ Counterfeiters can also easily copy a foreign company’s latest designs from the internet.

Many critics believe that the Chinese government does not have the sincere will to confront and eliminate infringement problems. For example, five counterfeit Apple stores operating in Kunming were discovered in $2011^{60}$ but the relevant Chinese authorities were able to shut down only two of them because the other three counterfeit stores were selling real Apple products. ${ }^{61}$ It was noted by one commentator that:

\footnotetext{
${ }^{56}$ Created by the authors from BSA data over the years.

${ }^{57}$ Wei Ran, 'Counterfeit Chinese Products Pose Global Threat', The Epoch Times, 17 October 2004, 1.

58 Ibid.

59 Ibid.

${ }^{60}$ Comment, 'China Shutters Fake Apple Stores', The Age (Melbourne), 27 July 2011.

61 These stores were counterfeit because they were not authorised stores of Apple Corporation, but were replicas of real stores using Apple's logos and branding. See Christopher Magood and Katrie Martin, 'China’s Copycat Phenomenon: Fake Apple Stores Still Booming in
} 
The proliferation of the fake stores underlines the slow progress that China's government is making in countering a culture of rampant piracy and widespread production of bogus goods that is a major irritant in relations with trading partners. ${ }^{62}$

However, this is not the only reason why intellectual property protection is still problematic in China. The problems of enforcement of rights in China are complex. Political, economic, and cultural factors also play their parts.

\section{B Cultural Factors}

What makes intellectual property so difficult to protect is that the subjects of the protection derive from the concepts, ideas, creativity and innovations of a person or persons. Traditional Chinese culture does not consider that unauthorised use of intellectual capital is morally wrong. According to traditional Confucian beliefs, a person is not to take individual credit for a creation, but must attribute it to society as a whole. This is because such creations would not exist if it were not for prior knowledge gained from others from the past. In other words, 'creating is a social act wherein many should be credited'. ${ }^{63}$ For many Chinese, copying is seen as a way of accepting and appreciating someone else's work or product. ${ }^{64}$ Susan Tiefenbrun has argued that 'stealing property from another individual is less a crime than owning something yourself', ${ }^{65}$ a view deriving from China's socialist past, where no one owned anything and everything belonged to society as a whole.

Whilst 'Western jurisprudence and scholarship about intellectual property have been inextricably linked to debates about the nature of real and personal

Southern China, on TealeafNation (4 June 2013) who note that '[i]n Lincang, a small city near the China-Burma border, three fake Apple stores have opened since the crackdown. These stores, which are a seven-hour bus ride away from Kunming, look and feel like real Apple stores, but to a trained eye, something is off' <http://www.tealeafnation.com/2013/06/ chinas-copycat-phenomenon-fake-apple-stores-booming-in-southernchina/\#sthash.eazRo8ir.dpuf>.

62 The Age, above n 60.

${ }^{63}$ William P Alford, To Steal a Book Is an Elegant Offence (Stanford University Press, 1995), 19-21, 56-65.

${ }^{64}$ A J McCall, 'Copyright and Trademark Enforcement in China' (2004) 9 The Transnational Lawyer 591.

${ }^{65}$ As quoted in Anders Egebjerg Dalsgaard, Protection of Intellectual Property in the People's Republic of China: Is It Really as Bad as It Looks? (Master Thesis, Aarhus School of Business and Social Sciences, Aarhus University, 2011) $40<$ http://pure.au.dk/portal/ files/36024216/Master_Thesis.pdf>. 
property ${ }^{66}$ this has not (until recently) been the case in China. Until 1981, the Chinese people still believed that 'all products of technology were the common heritage of mankind'. ${ }^{67}$ This notion of a common heritage is consistent with China's communist culture and its traditional beliefs. ${ }^{68}$

\section{Economic Factors}

It can be argued that a country's intellectual property protection regimes are greatly influenced by the economic conditions of that country. Whilst there has been great economic advancement in the last 25 years, China has only recently ceased to be classified as a developing country, according to the World Bank's classification data. ${ }^{69}$ The Chinese government today is primarily concerned with improving the living standards of its own people. It can easily turn a blind eye to illegal activities when the prosecution of such activities is in conflict with its economic interests. Currently, infringement occurs in many sectors of the Chinese economy, in particular in the areas of pharmaceuticals, chemical products, information technology ('IT'), consumer goods, and electrical equipment. In 2005, it was estimated that the production and sale of counterfeit goods contributed between 15 and 20 per cent of China's gross national income. ${ }^{70}$ Furthermore, tax considerations also play a part. Taxes are expected to be paid by all organisations operating in China. It is arguable, therefore, that when the government closes down infringing organisations, the collection of taxes is affected, and so turning a blind eye is often the preferred option of the local Chinese authorities.

66 Jonathan Ocko, 'Copying, Culture, and Control: Chinese Intellectual Property Law in Historical Context' (1996) 8(2) Yale Journal of Law \& the Humanities 559, 567.

${ }^{67}$ Chen, above n $10,347$.

${ }^{68}$ Ocko, above n 66, 562. Ocko noted that 'in sum, the intellectual property constituted by the common heritage of the past in general, and the enduring social truths of Confucianism in particular, belonged to the state'. See also the Qianlong Emperor's famous letter to King George III of England in 1793, in which he rejects King Gorge's wish to establish official diplomatic and trade relations with China: 'We possess all things. I set no value on objects strange or ingenious and have no use for your country's manufactures' < http://academic. brooklyn.cuny.edu/core9/phalsall/texts/qianlong.html $>$.

69 The World Bank, How We Classify Countries <http://data.worldbank.org/about/countryclassifications $>$. According to this data, China currently falls into the upper middle income country classification. This puts it just outside the group of countries that fall under lower and and middle income classifications. Those countries are considered by the World Bank to be developing countries. In 2012, the gross national income per capita in China was at \$US5740 compared to \$US3620 in 2009.

${ }^{70}$ Ian Heath, 'A Perspective on Intellectual Property Protection in China' (2005) 55 Growth 68, $74<$ http://search.informit.com.au/documentSummary;dn=296444293740993;res=IELBUS>. 
Whilst the state of economic development is not the only reason for poor enforcement, it nevertheless plays a role. ${ }^{71}$ Arguably, intellectual property protection in China 'cannot improve until overall economic conditions improve'. 72

\section{Local Protectionism}

The central government in China is the primary law-maker; however, the laws need to be implemented by local governments. ${ }^{73}$ It is here that local protectionism arises. Local officials' interests are not always consistent with those of central authorities. The production and sale of pirated and counterfeit goods can comprise a large proportion of a local economy, offering locals employment and contributing revenue to the economy. In addition, the performance of local government officials (including local judges) is assessed by the central government (the Chinese Communist Party) by reference to the local GDP. Therefore, the interests of local officials can be in direct conflict with the enforcement of intellectual property protection. In smaller towns and provinces it can be the local government officials who are actually protecting infringers of intellectual property because they are relatives and friends. Bribery at the local level can also be a problem, causing the interests of counterfeiters to take precedence over the interests of true trade mark owners, for example. ${ }^{74}$

\section{E Bureaucratic Rivalries and Overlapping Jurisdictions}

In China, a great number of regulations, rules and policies have been made by the NPC and its Standing Committee, the State Council and various ministries, bureaus and commissions. The circulars, opinions and notices of the Supreme People's Court also form part of the legal framework. As a result, the complicated and sometimes conflicting web of laws, rules and regulations in respect of intellectual property protection leads to overlapping jurisdictions among various enforcement agencies.

\footnotetext{
${ }^{71}$ Priest, above n 52: 'For example, the current average income for a Chinese local factory worker is $3500 \mathrm{RMB}$ per month. A legitimate copy of a DVD movie is approximately 100 RMB, whilst the cost of a pirated copy may only be 10 RMB. Faced with such a choice it is difficult to see, even with understanding and education, that a local Chinese worker would choose the original over the pirated copy.'

${ }^{72}$ Ibid.

${ }^{73}$ Commentary, above n 46, 405.

${ }^{74}$ Ed Perlman and Octavian Timaru, 'The Wild, Wild East: Winning Trademark Registration for US Companies in China' (2008) 20(2) Intellectual Property and Technology Law Journal 18.
} 
A successful action in confiscating pirated and counterfeited goods can bring the agencies huge benefits, such as cash, goods, equipment and the collection of fines. The agencies are then able to reward their own staff with cash bonuses. For this reason, competing agencies may claim jurisdiction over the same matter. Such bureaucratic rivalries can cause a lack of co-operation amongst the agencies and, arguably, do very little to further the protection of intellectual property rights.

\section{F Corruption}

Corruption is arguably the most serious problem for the regulation and reduction of infringement. In some cases, local officials or their relatives have a direct or indirect interest in the illegal intellectual property trade. Sometimes government leaders receive bribes from manufacturers of the pirated and counterfeited goods; in some cases, 'local enforcement officials ask for payments, case fees, or gifts, such as mobile phones from the trademark owners in exchange for conducting enforcement actions'. ${ }^{75}$

Corruption is common and generally well understood by the public. Pursuing an infringement action in a Chinese court is fraught with problems for a foreign owner. It is said that corruption permeates even the judiciary, and it is generally felt that there is a lack of judicial independence in China. ${ }^{76}$ This is despite the fact that the principle of judicial independence is recognised in both China's Constitution and other laws. ${ }^{77}$ It is said that Chinese lawyers spend a lot of money to develop good relations with judges, and that if one party to a lawsuit (or that party's lawyer) has some personal relationship with the judge, or with other people who can influence the judgment, then that party will almost certainly win. ${ }^{78}$ The Chinese do not view this practice as

\footnotetext{
${ }^{75}$ Chow, above $n$ 51, 30.

${ }^{76}$ See Ethan Michelson, 'Lawyers, Political Embeddedness, and Institutional Continuity in China's Transition from Socialism' (2007) 113(2) American Journal of Sociology 353, where he notes that 'the judiciary remains fused to the state, embedded in and subordinated to the rest of the government bureaucracy (ie, there is no meaningful separation of powers or judicial autonomy)'.

77 《中华人民共和国宪法》 [Constitution of the People’s Republic of China] (PRC) 1982, art 126: 'The people's courts shall, in accordance with the law, exercise judicial power independently and are not subject to interference by administrative organs, public organizations or individuals' <http://english.people.com.cn/constitution/constitution. html>.

${ }^{78}$ See Mo Zhang, 'International Civil Litigation in China: A Practical Analysis of the Chinese Judicial System' (2002) 25(1) Boston College International and Comparative Law Review 59, 94 where it is noted that 'many Chinese lawyers spend much of their time trying to find easy access to the presiding judge in lieu of traditional legal analysis'.
} 
corruption but simply as part of the accepted process. ${ }^{79}$ It reflects the traditional mode of operation of Chinese courts, and makes conditions very difficult for foreign investors and intellectual property owners.

Another major criticism of the enforcement of intellectual property rights in China is that enforcement through the courts lacks transparency:

[C]rime enforcement in China is typically conducted in waves of crackdown campaigns ... [that are] easy to publicise and the narrow focus ... tends to create enforcement statistics which make the enforcers appear to be taking conscientious action and working hard. ${ }^{80}$

This brief explanation of the intellectual property laws in China, and the associated problems of enforcement, gives some contextual basis to the study undertaken. Below, the protection issues faced by Australian managers who operate businesses in China are explored in some detail.

\section{The InVESTIGATION: HOW IMPORTANT ARE INTELLECTUAL PROPERTY PROTECTIONS FOR Australian ORganisations CONDUCTING Business IN CHINA?}

\section{A Method}

A qualitative approach was undertaken for this research in which an understanding of 'doing business in China' from the point of view of the Australian manager-interviewees was sought. ${ }^{81}$ The study utilised in-depth qualitative interviews to examine their experiences and opinions. Potential interview participants were identified through a variety of sources, including the Australia China Business Council Victoria membership list, public domain media, and through the researchers' own contacts. Invitations to participate were emailed to potential interviewees, and 43 people agreed to participate. Non-respondents to the initial contact were pursued by follow-up telephone calls.

\footnotetext{
${ }^{79}$ Jim Guan, 'Guanxi: The Key to Achieving Success in China', Sino-Platonic Papers, No 217, December 2011. Guan notes that '[l]oosely translated, the term refers to connections or relationships between people. Guanxi implies preferential treatment given to the partners in an exchange, in the form of easy access to limited resources, increased access to controlled information, credit grants, and protection from external competitors': at 2.

${ }^{80}$ M L Riley, Protecting Intellectual Property Rights in China (Sweet \& Maxwell, 1997) 92.

${ }^{81}$ Robert K Yin, Case Study Research: Design and Methods (Sage Publications, $4^{\text {th }}$ ed, 2009).
} 
Once individuals agreed to participate, the aims and background of the study were explained to them, together with the processes undertaken for ensuring the confidentiality of any information gathered and the protection of their anonymity. Interviews predominantly took place at the interviewee's office. The interviews lasted approximately 60 minutes, and were audio recorded and then manually transcribed. A semi-structured interview guide (available from the authors) was developed for the interviews, and interviewees were questioned about their business activities and any intellectual property issues they faced when doing business in China. In the majority of cases, the interviewees held senior managerial positions within their organisations.

The interview transcripts were later analysed by the researchers using NVivo (Version 7.0) software. NVivo is a categorising tool, which enables segments (nodes) of larger blocks of data to be 'tagged' and linked into hierarchical patterns (trees) on the basis of thematic linkages appearing in the data. ${ }^{82}$ This software allowed the researchers to categorise, sort and arrange the information collected from the survey participants.

\section{$B \quad$ The Sample}

A total of 43 managers from 40 Australian organisations that had internationalised to China were interviewed for this project. The largest sector in the sample consisted of organisations in the manufacturing industry (10/40). Other industries investigated were business and property services (5); building, construction and engineering (3); education (4); agriculture, forestry and fishing (4); and finance and insurance (3). A small number of further organisations were dispersed across various industries such as accommodation, restaurants and cafes, mining, publishing, IT, government, administration and defence, and health and community services.

Several entry modes into China were represented in the sample. Eight participants used the fly-in-fly-out mode; two did business in China through the offices of representatives; one had a registered office in China; six were involved in joint ventures with a Chinese partner; five used agents and partners to source customers or, in the case of education institutions, to source students from China; 13 were wholly-owned foreign entities, that is entities in China which are wholly owned by Australian firms; one was a licensor (licensing its products to be manufactured and sold in China by a Chinese entity); one was in a buyer relationship (sourcing its goods from China to sell in Australia); six were exporting goods to China, and one was assisting export to China. The most common locations for dealings in China by these

\footnotetext{
${ }^{82}$ QSR International, NVivo <http://www.qsrinternational.com/products_nvivo.aspx>.
} 
organisations were Shanghai (24), Beijing (15), Guangzhou (9), Shenzhen (4), and Tianjin (6).

\section{Findings}

Given the concerns surrounding intellectual property protection in China, it was hypothesised that Australian organisations would be concerned about their level of protection when internationalising to China. In addition, the researchers theorised that such organisations would pursue legal action in order to protect against any infringements of their intellectual property in China.

Interestingly, the findings did not fully support the preliminary assumptions held by the researchers. For example, one respondent from the building, construction and engineering industry stated:

[I]f someone ripped us off with a design, we probably would not pursue it through the legal system because of our perceived lack of trust in it.

Another respondent from a manufacturing firm shared similar sentiments:

But we'll definitely not look to pull anyone up on any intellectual property issues in China. I'm certain it wouldn't even stand up.

The respondent from the first firm did indicate that one of its Chinese partners had misappropriated intellectual material. Its response was not to work with that partner again. From this, the researchers deduced that where one-off incidents occurred, a common way to deal with intellectual property infringement was not to do anything about it because of the expense and time involved.

The general opinion of the respondents was that further progress in intellectual property protection in China was necessary:

Now, it's still got a way to go in controlling piracy of intellectual property.

Another respondent also indicated its understanding of why infringement was still problematic in China, indicating that a lack of enforcement was the major issue:

We are well aware of the lack of sophistication of the IP protection mechanisms in China, which is to do with their entrepreneurial spirit and their idea that if they can make a buck, they should be able to make a buck. 
Some organisations articulated that intellectual property protections were not a major issue for them. For example, a representative from a mining company said:

[W]e have nothing to copy, as we are just supplying resources to China.

Similarly, an agricultural company running educational programs in China for agricultural products said that protection was not a problem for the company because it believed that it was not worthwhile for potential pirates to copy its educational programs. The manager did comment, however, that the company was careful about the information it provided when running its programs, just in case someone did actually want to copy anything.

Representatives from universities and TAFEs had similar views: they were sharing courses and subject materials with Chinese universities, and thought that 'theoretically' these universities could steal the information, but did not think that they would.

A representative from a banking organisation commented that misappropriation was not a major problem for it, because a lot of its intellectual capital is situated within people, management processes, and what was referred to as its 'organisational DNA':

But we are lucky that we are a Bank ... I think that manufacturing companies have more of an issue with IP than we do.

A representative from a manufacturing company said that it would be easy for competitors to steal the designs of its products; however, the high quality of the products would be a deterrent:

[P]art of our competitive advantage is our quality, and the way we manufacture these; this is something that would be difficult for [Chinese] competitors to replicate, and, therefore, at the present time, we are not so worried about our IP being stolen.

Another respondent from a marketing consulting company felt that misappropriation of intellectual capital was not an issue because there really was not much it could do about it. If it became a problem, the company would build that factor into its cost base:

We have a number of software products we've developed that measure channel performance and market performance and, I guess, if we sold those in China anything could be copied. But how we go about stopping that I wouldn't have a clue. I guess we would just have to charge enough for it so 
that if our client did steal our intellectual property, then it doesn't really make any difference to us.

Some respondents felt that intellectual property protection in China was very stringent, more so than in Australia:

Some of the penalties for infringing intellectual property are very punitive, because a lot of them might be relating to someone burning 50 CDs. If you've got a sawmill machine that is maybe turning out a million dollars' worth of timber, you could get in serious trouble if you were breaching someone's patents.

A manufacturer of automotive components suggested that China's accession to the WTO in 2001 meant that Chinese companies and individuals should theoretically follow intellectual property laws, and therefore it was not too concerned. But the manager did note that the company did not want to reproduce a number of its patented products in China because it was worried about having its inventions copied:

In effect, part of our joint venture arrangement is that all information is available to ABC automotive. For IP here in Australia, we will protect and restrict the use of that and we put filters in place in our business so they won't be exposed to China. We also have a couple of our own patented technologies that we are selling in North America, and we've taken the decision not to take those to China yet because we're not comfortable that the protection is sufficient yet.

A company in the IT industry, which stated that it had software-copying protection built into its product, mentioned an alternative standpoint. The representative from this company thought it was inevitable that the software would be copied but, ultimately, he thought that copying was good marketing:

I think there might be some pirated versions out there. In some ways pirated versions is getting your brand out and about. Ultimately, you'll get them back. In accounting software, our research would suggest that the piracy is quite low because if you are running your business do you want your data files on something that is going to get corrupted? Probably not ... You are prepared to buy a video or a game or whatever. If it crashes, fine, but if you started to put a year's worth of accounting data in, you don't want it to crash.

One organisation in the study had gone about the process of registering its trade mark in China:

We only registered our logo and name as a trade mark in China about two or three weeks ago. So we haven't used that in any way as yet. We haven't 
tested whether or not we have any grounds to use that. We've put it in place anyway.

The manager also commented on how he would enforce a breach:

And I think it's good to be proactive about those things. You might not follow up on them but at least you can say, here's a nasty letter to them saying, 'Don't use it again. If not, we'll take you to court', and most people at that point would probably not use your logo or something again. So, I totally agree. We have been registered now for a while, but we may never take anyone to court on it because we won't waste the money.

The comments above suggest that the managers probably would not go to the extent of suing someone in a court of law because of the time and expense involved. A representative from a law firm talked about the Chinese ingenuity in applying reverse engineering to products in order to work out how they are built:

I have had problems with reverse engineering ... so I warn clients to be very, very careful about handing over information unless they need to, unless they absolutely have to. They shouldn't hand it over and they shouldn't leave equipment there on site unless absolutely necessary, because it's too tempting for someone to try and take it apart.

Interestingly, a book manufacturer that had a licensing agreement with a stateowned enterprise in China commented that since its products were priced very cheaply, there was less incentive for others to pirate them:

To some extent, because our product, which is locally produced, is low price, it's Chinese Yuan price - there is less incentive for pirates to pirate this because it's relatively cheap for people to buy.

\section{Discussion}

The interviewees revealed that the majority of organisations involved in the study had done little to protect their intellectual property in China, and they would therefore respond reactively when infringement did become an issue. Some of the organisations had registered their intellectual property with the relevant bodies, but the majority had not, using other means of protection.

Given these findings, the authors consider that many organisations are not protecting their intellectual capital sufficiently, especially when doing business in China. Misappropriation of intellectual material can affect an 
organisation's competiveness, as well as its economic growth. For example, the United States Senate Report in 2012 noted:

Innovation drives economic growth and job creation. Protection of intellectual property (IP), through patents, trademarks and copyrights, is critical to ensuring that firms pursue innovation. Counterfeiting and piracy erode the returns on innovation and slow economic growth because of the negative impacts on companies, consumers and governments. ${ }^{83}$

The study highlights the shortcomings of many organisations' approaches to protection. It is imperative that when organisations enter China they analyse their business and/or products and services to determine the possibility that their intellectual products will be copied. This analysis should be continuously undertaken, as changes occur rapidly in the Chinese market.

Those organisations which fell into a 'low-risk category' — for example, the manufacturing organisation that produced high-quality goods - felt that they had a competitive advantage which would be difficult to imitate. Even so, over time, as Chinese competitors improve their capability, this approach may not be so effective.

The study indicated that different approaches to protection were taken by those organisations that fell into the 'higher-risk category'. Some organisations accepted the risk and went ahead with introducing their products or services into the Chinese market nonetheless. Some factored infringement into their cost base, whilst others felt that they would deal with infringement on a case-by-case basis.

The authors argue that it is imperative for those organisations which fall into this high-risk category to consider intellectual property protection in a positive and proactive manner. This can be done in a number of ways. The authors suggest some approaches that can be taken by Australian organisations and other foreign firms doing business in China.

\section{Intellectual Property Protection Strategy}

The authors' major recommendation for organisations considering entry into the Chinese marketplace is to develop an 'organisation focused' strategy for protecting their intellectual property. They have therefore developed a framework that organisations can use when conceptualising how to protect

\footnotetext{
${ }^{83}$ Chairman's Staff of the United States Congress Joint Economic Committee, The Impact of Intellectual Property Theft on the Economy (August 2012) $1<\mathrm{http}: / /$ www.jec.senate.gov/ public/index.cfm?a=Files.Serve\&File_id=aa0183d4-8ad9-488f-9e38-7150a3bb62be>.
} 
their intellectual assets (see Figure 3 below). This framework includes using the law, but also utilising the organisation design when developing intellectual property protection systems.

A holistic approach to protecting intellectual property is suggested, and prior research in the field would indicate that the use of both legal and organisational strategies when designing interventions would be useful. These strategies would not be fool proof and would not prevent infringement outright; ${ }^{84}$ however, they do go some way to reducing and managing the risks and are therefore useful in a manager's toolbox when internationalising to China.

Figure 3: Intellectual Property Protection Strategy

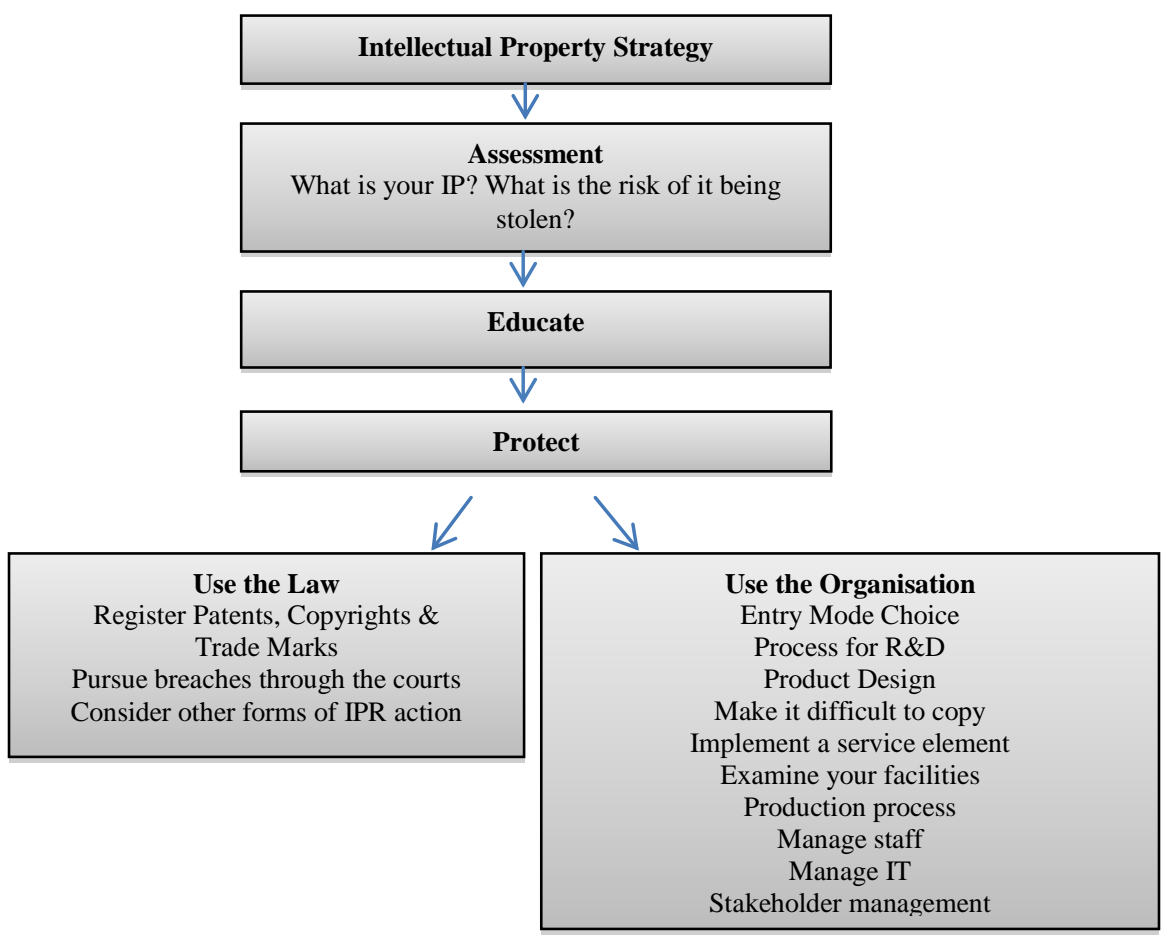

${ }^{84}$ Gupta and Wang, above n 27. 


\section{A Assessment}

\section{$1 \quad$ Work out What Your Intellectual Property Is}

The first step for an organisation is to work out what intellectual property it owns. Intellectual property, at its broadest, is defined as:

the legal rights, which result from intellectual activity in the industrial, scientific, literary and artistic fields. ${ }^{85}$

For industrial organisations, intellectual property can include inventions, industrial processes and management know-how, and for other businesses it can include brand and image, business planning and corporate strategy. Some organisations may not have any material that is worth copying, as in the case of the mining company included in the study.

\section{2 \\ Work out the Risk of Your Intellectual Property Being Stolen}

There are many kinds of intangible assets that are subject to copying, from an invention, a brand name, a book, and a film to a trade secret or artistic design. ${ }^{86}$ Some organisations are not subject to infringement problems. However, all organisations should undertake a risk analysis to decide how much risk there is of their intellectual property being infringed, and whether such an infringement will affect the competitive advantage of the organisation. Some intellectual property would be very difficult to access, for instance, management know-how and processes, whereas copying a movie from a DVD is as easy as putting a DVD into a computer and copying it to another disk. A rule of thumb would be: if the organisation manager can think of a risk, then a competitor could also see that vulnerability. Therefore, the organisation should seek to manage the risk.

\section{B Educate}

The next step in the process is to effectively educate managers and employees on the intellectual property environment in China, and the strategies that organisations can use to protect it, which can include training programs and manuals. It is also advisable for foreign investors with intellectual assets in China to conduct feasibility studies of the market. They should look at the

\footnotetext{
85 WIPO, 'Intellectual Property Handbook' (13 August 2013), <http://www.wipo.int/export/ sites/www/freepublications/en/intproperty/489/wipo_pub_489.pd>.

86 IP Australia, What is IP? (12 December 2012) <http://www.ip australia.gov.au/understanding-intellectual-property/what-is-ip/> .
} 
type of counterfeiting that is already occurring and try to avoid those provinces where counterfeiting is rife. New investors should make sure that they enter the market with a 'zero tolerance' approach to infringements and not let their guard down. It is arguable that this may help deter infringements and 'prevent violations from increasing rapidly as they might otherwise if reaction time is slow or half hearted' ${ }^{87}$

\section{Protect}

\section{Use the Law to Protect Against Copying}

It is imperative that an organisation look at how to protect its intellectual property in the local market in China using the available laws. Organisations need to stake their legal claim to their intellectual assets immediately upon entering the Chinese market (if not before), and seek to enforce it wherever and whenever possible.

\section{a Register Patents, Copyright and Trade Marks}

In order to ensure that Australian or other foreign-owned intellectual property is protected under Chinese law, it is essential that it is registered with the relevant offices in China. This is because of the strict 'first-to-file' policy followed in China. When introducing a new technology or invention to China, organisations should apply for a patent under the Chinese Patent Law to ensure that the organisation has the right to use the technology. ${ }^{88}$ Similarly, for copyright materials, organisations should register them through the Copyright Bureau of China, so as to give them recognised protection. With respect to trade marks, trade mark owners can use their western trade marks or create trade marks using Chinese characters to deal with Chinese language issues. ${ }^{89}$ Chinese consumers generally prefer to see Chinese language versions of a foreign trade mark. In any case, when the trade mark is registered, the name needs to be translated into Chinese. ${ }^{90}$ As China follows the 'first to file' rule, unless the trade mark is 'well known', and hence protected under the

\footnotetext{
${ }^{87}$ IP Australia, Principles for Protecting IP for Business Trading in China (2011), 2 $<$ http://www.ipaustralia.gov.au>.

${ }^{88}$ Gupta and Wang, above $n 27$.

89 Baker and McKenzie, Intellectual Property Guide: China (2012) $16<$ http://www. bakermckenzie.com/files/Uploads/Documents/China\%20Update\%202012/bk_china_intellect ualpropertyguide_jan12.pdf > .

${ }^{90}$ Ibid.
} 
Paris Convention, ${ }^{91}$ it is important that businesses apply to register their trade mark promptly, so that they are not prohibited in the future to use that mark.

\section{b Pursue Breaches}

Organisations should also seek to develop relationships with a local Chinese or international law firm. This is so the law firm is familiar with the organisation's situation, can advise appropriately on intellectual property issues, and can pursue legal issues if they arise. This also signals to other firms that the organisation is serious about pursuing infringements. If there is a breach of the law, organisations need to pursue that breach immediately.

\section{c Consider Other Forms of Action}

Whilst it can be beneficial to engage a local law firm to deal with breaches of intellectual property, the authors note that the process of litigation in China can be problematic. An action for infringement can, however, also be brought under the administrative arm of the Chinese government, in which case the enforcement of a particular right is undertaken by the relevant government department. The SAIC Bureau administers intellectual property registrations and oversees market conditions. They employ experienced professionals who can often handle cases of infringement more quickly and effectively than the courts can. Furthermore, they have their own market information database, which makes them generally better equipped to investigate infringement and regulate the market.

Alternative dispute resolution ('ADR') ${ }^{92}$ processes are also becoming more popular in China in dealing with intellectual property infringement. ADR is generally less costly than litigation and may resolve a dispute quickly and without the intervention of the courts or government authorities. ADR procedures, whether used independently of or in conjunction with litigation, can often substantially reduce the cost and other burdens of litigation, and bring about solutions, which are unavailable through the court system. For

\footnotetext{
${ }^{91}$ Ibid 12.

${ }^{92}$ ADR includes dispute resolution processes and techniques that fall outside of the government judicial process. ADR is generally classified into at least three subtypes: negotiation, mediation, and arbitration. In negotiation, participation is voluntary and there is no third party who facilitates the resolution process or imposes a resolution. In mediation, there is a third party, a mediator, who facilitates the resolution process (and may even suggest a resolution, typically known as a 'mediator's proposal'), but does not impose a resolution on the parties. In arbitration, participation is typically voluntary, and there is a third party who, as a private judge, imposes a resolution. Arbitrations often occur because parties to contracts agree that any future dispute concerning the agreement will be resolved by arbitration.
} 
example, many trademark disputes are especially suited to arbitration, not only because arbitration usually costs less but, more importantly, because the confidentiality of the procedure protects trade secrets. Also arbitration affords the procedural flexibility that helps the trademark holder to save time. By quickly resolving the problem and eliminating infringement, the trademark holder can significantly mitigate losses and therefore lessen the actual harm done to its business reputation. The longer the infringement persists, the greater the economic loss and reputational harm to the trade mark holder.

\section{$2 \quad$ Use the Organisation}

\section{a Internationalisation of Production}

It may be preferable for organisations that fall into the 'high risk category' to manufacture their products themselves rather than license production to local Chinese organisations. This is known as the internalisation of production. According to Dunning's eclectic model, ${ }^{93}$ where the transaction costs of creating, monitoring and enforcing contracts in regard to property rights in a country are high, firms should internalise their production rather than license or contract out the manufacture to other producers. To illustrate the danger of not internalising production, consider the following:

A producer of earthmoving equipment licensed the production of particular motors to a Chinese organisation. In the process, the producer provided IP to the Chinese organisation. The Chinese organisation appropriated this IP and is now highly likely in the future to become the number one producer in the world. ${ }^{94}$

Had the management of the production company internalised the production of these motors, this situation would have been less likely to arise. Therefore, it is vital that organisations choose appropriate entry modes that protect their intellectual property. Of course, economic factors need to be considered in this approach.

\section{b Locating the Research and Development Process}

One previous trend was for organisations to have their research and development ('R\&D') processes based in developed countries that have an R\&D culture, good education levels and infrastructure. However, this trend

\footnotetext{
93 John H Dunning, 'The Eclectic Paradigm of International Production: A Restatement and Some Possible Extensions' (1988) 19 Journal of International Business Studies 1, 11.

${ }^{94}$ Email from Anonymous Correspondent to Authors, 4 June 2009.
} 
has been changing, with organisations starting to locate their R\&D operations in China. ${ }^{95}$ To ensure that entire R\&D efforts cannot be copied, foreign organisations should locate their R\&D cells across multiple locations in different countries. As a result, potential infringers would have the ability to copy only part of the intellectual property, not all of it.

\section{c Design Products and Price with a View to Preventing Misappropriation}

Organisations can reduce copying by competing only in value segments, and not premium segments of the market. ${ }^{96}$ For instance, per capita income in China is low, at around US\$8394 (PPP) (data for 2011). ${ }^{97}$ Therefore, if an organisation offers expensive products, it will have created a desire and, hence, a market for Chinese organisations to copy them. However, if organisations designed cheaper products, which the average Chinese consumer could afford to buy, it can be argued that there will be less likelihood of the product being copied. One of the respondents of the survey, a manufacturer of books (see above in Part IV, C), indicated that because its products were low in price, there was less incentive for piracy to occur.

\section{d Make Products Difficult to Copy}

It has been suggested that the Chinese will seldom put much effort into the independent copying of inventions that cannot be copied easily. ${ }^{98}$ Rather, they will usually wait to be trained by the foreign business. As a result, the motivation of most Chinese companies that work with foreign businesses is the desire to acquire technology, trade secrets and know-how via training from the owner of the intellectual property. This training can occur when Chinese companies work with foreign businesses, in technology licensing projects, in joint ventures, in original equipment manufacturing, and also in product design and development.

Investors entering the Chinese market in joint ventures with Chinese companies should be vigilant in their choice of such partners. They should be very careful to protect trade secrets from their partners and their employees. It

\footnotetext{
${ }^{95}$ Gupta and Wang, above n 27.

${ }^{96}$ Ibid.

${ }^{97}$ Department of Foreign Affairs \& Trade, China Economic Fact Sheet (December 2012)

$<$ http://www.dfat.gov.au/geo/fs/chin.pdf >.

98 Dan Harris, 'Protecting Your Intellectual Property in China, Part 1' (July 2011), $<$ http://www.chinalawblog.com/2011/06/protecting_your_intellectual_property_in_china_part i.html>.
} 
is not uncommon for Chinese employees to misappropriate trade secrets and use them to establish their own enterprises. To avoid this, both business and employment contracts should contain secrecy, confidentiality and nondisclosure clauses to ensure that maximum protection is given under local Chinese law. Organisations could consider employing licensing and trade secrecy and non-circumvention agreements with employees and joint venture partners. ${ }^{99}$ Organisations should draft manufacturing and licensing contracts that articulate the scope of their intellectual property, as well as the financial penalties if infringement occurs. It is strongly recommended that a Western lawyer fluent in Chinese vet the Chinese version of these contracts.

\section{e Incorporate a Mandatory Service Element into the Product}

Infringement of intellectual property becomes less attractive if the relevant product requires after-sales consulting services, product support, and ongoing maintenance. Similarly, requiring customers to input software codes annually to maintain the functionality of the product would also reduce piracy.

\section{f Check for Bugging}

Bugging of offices is not uncommon in China. In one example, a Western organisation found that its Chinese office premises had been bugged with recording devices that had been planted by the local Chinese government. The government was subsequently sharing the knowledge gained with state-owned enterprises. ${ }^{100}$ To prevent this situation from happening, organisations should properly inspect their premises to protect against such bugging.

\section{g Split Up Production across Multiple Locations}

In addition to splitting up key R\&D cells, organisations are also recommended to split up their production across various segments of a product to ensure that a competitor cannot copy the whole product or production process. ${ }^{101}$ This was the strategy of an Australian inventor/producer of surfboard straps and locks, which, for economic reasons, wished to have these locks produced in China. Its approach was to split the process up into three sections, and to source production from three different manufacturers to ensure that another

\footnotetext{
${ }^{99}$ Ibid.

${ }^{100}$ Gupta and Wang, above n 27.

${ }^{101}$ Australian Broadcasting Corporation (ABC), 'Riding on China’s Success', Catapult, 2008 <http://www.abc.net.au/catapult/indepth/s1496179.htm>.
} 
manufacturer does not copy its inventions. ${ }^{102}$ Although this might be costly and not possible for all producers, it is a helpful way to protect against infringement.

In addition, having the most crucial element of the product produced outside of China could also reduce the risk. That element could then be shipped to China for final assembly, which reduces the ability of other organisations to copy the entire design of the product. Alternatively, product components could be produced through various suppliers in China, and other countries, and sent to another country for final assembly.

\section{h Manage and Develop Harmonious Relationships with Staff}

Intellectual property leakage can result from disgruntled staff, ${ }^{103}$ or from staff moving from organisation to organisation. Organisations should try to develop harmonious relationships with staff who will develop an affinity with the organisation, and will consequently be less likely to give away trade secrets. Alternatively, an organisation may allocate its core manufacturing processes to their most trusted employees. ${ }^{104}$ This ensures that not all employees have access to important information, which can easily be shared with other organisations.

\section{i Manage Information Technology}

Preventing the copying of proprietary and code data is especially important for software and services businesses. Organisations that wish to protect this type of information should seek to prevent employees taking files or memory devices from demarcated zones. In addition, organisations should prevent the transfer of files outside of the organisation's server. Encryption of data could also be an effective form of protection.

\section{j Stakeholder Management}

Developing relationships with government bodies in China may assist foreign organisations to protect their technology. If a foreign organisation has a good

\footnotetext{
102 Ibid.

${ }^{103}$ Cisco Systems, Inc, Data Leakage Worldwide: The High Cost of Insider Threats (2008) $<$ http://www.cisco.com/en/US/solutions/collateral/ns170/ns896/ns895/white_paper_c11506224.pdf $>$. ${ }^{104}$ Ibid.
} 
relationship with the Chinese government, the government can assist with the protection of its intellectual property. Through these relationships, foreign organisations could also lobby the government and communicate the message that protecting intellectual property rights is integral to the development of an innovation-based economy.

\section{k Keep on Innovating}

The final strategy, simply put, is to keep on innovating at a lightning pace. ${ }^{105}$ Copycat competitors will not be able to keep up with innovative organisations and the technology they develop. Once an organisation has introduced a new technology, the next innovation should already be on the drawing board and have an anticipated release date.

In summary, the authors recommend that organisations doing business in China should always keep intellectual property issues in mind, and should seek to implement a variety of strategies in order to protect themselves from infringement where this is practical and possible. By considering and implementing some of the strategies described above, organisations will be armed with a proactive strategy which will go some way to managing the risks to intellectual property in China.

\section{Conclusion}

Over the last 40 years China has implemented and reformed its intellectual property legislation, making it apparently safer for owners of foreign trademarks, patents, and copyrights. It has joined the WTO and WIPO and acceded to many international conventions and agreements including the UCC, and the Berne, Paris and Madrid conventions. It has become a major international trade partner for many countries. Indeed, since 2008, China has become Australia's largest trade partner. However, despite the myriad of legislative protections available to a foreign organisation doing business in China, many problems still exist with the protection of intellectual property. It is recognised that China is by far the world's leading infringer; in the last 25 years, it has become the main source of global piracy and counterfeiting. It has also been noted in this article that the Chinese government may not have had sincere intentions in confronting and eliminating infringement problems. The underlying problems of enforcement of the intellectual property laws in China are complex. Political and economic issues, local protectionism, corruption, and even cultural factors all play their part in infringement.

${ }^{105}$ Harris, above n 98. 
The examination of the 40 Australian organisations participating in this qualitative study revealed that the majority of the organisations did little to protect their intellectual assets, and many of them did not have adequate protection strategies in place. Many of the respondents believed that protection was not an issue for their organisations, or that their Chinese competitors lacked the skill and know-how to copy their technology or products. This attitude suggests that Australian organisations may be vulnerable to having their intellectual property infringed.

Despite these complacent attitudes, it is argued that once a foreign organisation (especially one in the high risk category) decides to enter the Chinese market, there are various practical issues it should address. In order to reduce the risk of infringement, the authors have suggested various protection strategies. These strategies all focus on an assessment of risk, the education of managers and employees, and legal and practical methods of protecting intellectual capital. The suggested strategies employ a two-pronged approach - the use of the legal system on the one hand, and organisational design on the other.

The opening of China's borders to allow foreigners to 'chase the dragon' in 1979 was just the beginning of economic, political and legislative changes. Arguably, further economic growth in China will bring better protection for intellectual property owners in China. As the country and its people prosper, intellectual property rights will be further recognised. Until then, the strategies for protection suggested by the authors can be employed to minimise the current and very real risks. 
